\title{
Learning from the past - the origin of wood
}

\author{
by Rodney Arthur Savidge ${ }^{1}$
}

\begin{abstract}
Trees were on Earth 394 million years ago (394 Ma) as spore-producing Archaeopteris progymnosperms having largediameter trunks of secondary xylem (morphotype Callixyon) produced by vascular cambium. Plants of smaller stature with primary xylem cores were present in Late Silurian (416 Ma), but they lacked cambium and it remains unclear how and when the first trees evolved. Progymnosperms faded and gymnosperms arose during Middle Carboniferous, and conifers, ginkgos, cycads, tree ferns and cordaites were well established by the Carboniferous-Permian transition (299 $\mathrm{Ma}$ ). Woods of the earliest conifers were different from those of today, and not until Late Triassic (220 Ma) did any begin producing secondary xylem similar to modern woods, the xylem phenotypes of Cupressaceae and Araucariaceae emerging much earlier than those of Pinaceae and flowering plants. Conifers have persisted and done relatively well despite major extinction events, severe climate change, insectivory, herbivory and microbial activity, all of which were in effect before as well as during the appearance of trees on Earth. Approximately 600 conifer species continue to exist, and the survivors presumably possess the physiological fitness needed to adapt to an ever-changing biosphere. However, this is speculative because their physiology remains less than well understood. Forestry interventions such as planting one species to the exclusion of others have the potential to exacerbate as well as sustain the ongoing existence of our remaining conifers.
\end{abstract}

Key words: bordered pit, cambium, cell biology, cellulose, evolution, lignin, paleobotany, protoplasmic autolysis, secondary growth, wood formation, xylogenesis

\section{RÉSUMÉ}

Les arbres sont apparus sur Terre il y a 394 millions d’années (394 ma) sous forme d'un progymnosperme Archaeopteris produisant des spores et qui avait des vaisseaux de fort diamètre de xylème secondaire (morphotype Callixyon) produits par le cambium vasculaire. Des plantes de plus petite taille comprenant des vaisseaux primaires de xylème étaient présents à la fin du Silurien (416 ma), mais navaient pas de cambium et nous savons pas comment et quand les premiers arbres sont apparus. Les progymnospermes ont disparu au milieu du Carbonifère alors que les gymnospermes se développaient et que les conifères, les ginkgos, les cycadales, les fougères arborescentes et les cordaites étaient bien présents lors de la transition du Carbonifère au Permien ( $299 \mathrm{ma}$ ). Le bois des tous premiers conifères était différent des conifères actuels et ce nest pas avant la fin du Triasique $(220 \mathrm{ma})$ qu'ils ont commencé à produire un xylème secondaire semblable à celui retrouvé dans les bois actuels, les phénotypes de xylème des Cupressacées et des Araucacées émergeant beaucoup plus tôt que celui des Pinacées et des plantes à fleurs. Les conifères ont traversé les époques et se sont relativement bien maintenus compte tenu des événements catastrophiques d'extinction, des changements climatiques radicaux, de lactivité des insectivores, des herbivores et des microbes, tous étant déjà en activité bien avant et durant l’apparition des arbres sur la Terre. Près de 600 espèces de conifères sont encore présentes et les survivants possèdent probablement l'aptitude physiologique requise pour s’adapter à la biosphère sans cesse en changement. Cependant, il s'agit d'une spéculation parce que la connaissance de leur physiologie demeure encore imparfaite. Les interventions forestières comme la plantation d'une espèce au détriment des autres pourraient potentiellement entraver la poursuite de l'existence des autres conifères.

Mots clés : tube criblé, cambium, biologie cellulaire, cellulose, évolution, lignine, paléobotanique, protoplasme, autolyse, croissance secondaire, formation du bois, xylogénèse

\footnotetext{
${ }^{1}$ Professor, Faculty of Forestry and Environmental Management, University of New Brunswick, P.O. Box 44555, Fredericton, New Brunswick E3B 6C2. E-mail: savi@unb.ca
} 


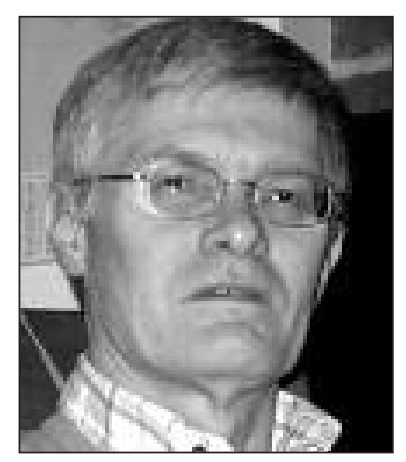

Rodney Arthur Savidge

\section{Introduction}

Forestry is the art and science of managing healthy forest ecosystems in perpetuity. Within that definition, a healthy forest ecosystem is not simply a productive one but one finely balanced for the sustainability of all species contributing to its existence. Trees are the heart and beauty of every forest ecosystem, and it is difficult to identify any kind of life less demanding on, or more important for continuing existence of, all living things on terrestrial Earth. Forestry has nevertheless chosen to favour some and discriminate against other tree species based mainly on economic considerations. Moreover, the primary aim of the genetics side of forest science has been to transform the favoured into "improved" clones, evidently overlooking the fact that the physiology of the wild tree within a biodiverse community embodies survival fitness achieved by repeated challenges over millions of years. The challenge for foresters is to see and manage every tree not merely as a wood-producing biofactory but also as an extraordinary organism having an ancestry extending back long before the advent of man.

Many scientists are concerned that Earth is presently in the process of the most rapid mass extinction of its entire history. An accurate estimate of the number of species in existence remains to be attained (May 1988), but Mayhew et al. (2008) predicted imminent extinction of $50 \%$ of all plant and animal species, and Thomas et al. (2004) estimated that a million extant species could be extinct by the year 2050. American Museum of Natural History Provost of Science Michael Novacek was quoted as saying, "I can think of no generation of scientists that has faced a greater challenge than we confront today, for no other generation has stood at the crossroads between the continued existence of the Earth's biological diversity and an irrevocable catastrophe to the biota. Our responsibility as researchers is nothing short of organizing a scientific initiative as complex and daunting as putting a human on the moon, with the ultimate goal of ensuring that life as we know it continues to exist" (American Museum of Natural History 1998).

Throughout the long history of trees, many conifers as well as co- and pre-existing species have succumbed. However, fossils remain and provide clues about life and climate of past eras. Permineralized wood retains much of its organic composition and anatomical data, and that information is useful in understanding where our trees came from, possibly also for predicting where they may be headed.

\section{Background to My Research}

"This Petrify'd substance resembled Wood, in that...the whole piece retain'd the exact shape of Wood, having many of the conspicuous pores of wood still remaining pores..." John Evelyn (1664) in Sylva, quoting Robert Hooke.

Years ago, my ongoing interest in discovering how our living conifers make wood led me to wonder about the origin of cambium and how it may have evolved over geological time.
I found little information on permineralized cambium in the literature, but a bark-clad petrified branch discovered in Arizona's Petrified Forest National Park (PEFO) enabled an attempt at direct observation. Cambium in that ancient conifer unfortunately was not well preserved, but the investigation led to observations on the anatomy of Late Triassic ( 210 Ma) bark and wood. Arthropods evolved with plants (Labandeira 2006), and insect bore holes and a developing larva were found in the bark and wood, respectively (Ash and Savidge 2004).

My graduate studies had taught me how to deduce some aspects of cambial activity from the anatomy of secondary xylem (Savidge and Farrar 1984), and during my undergraduate years I had learned to create taxonomic order from a pile of diverse wood blocks based on their many interesting micro-features. Thanks to that preparation, a morphotype of conifer wood indicative of novel cambial activity was identified (Savidge and Ash 2006), and a number of additional kinds of wood was subsequently proposed, with the conclusion that conifers of Late Triassic Arizona were more biodiverse and some more similar to present day trees than previously recognized (Savidge 2006, 2007).

Those PEFO investigations helped me to appreciate that there is immense scope in paleobotanical research for advancing understanding not only of the origins and earliest phenotypic expressions of wood (the dominant form of biomass on terrestrial Earth since $394 \mathrm{Ma}$ ) but also of the diverse kinds of wood produced by trees that once lived but are no more. Many discoveries undoubtedly remain to be made, and based on my observations of nuclei in sapwood ray cells, not the least will be that some long-extinct species may one day come to life again through biotechnology. However, resurrection of an extinct species will require an immense effort, whereas conservation forestry aimed at prevention of species extinction is likely to be considerably less demanding.

\section{From Whence Woody Plants?}

From the standpoint of intelligent design and creation, plants had their beginnings as stated in the Bible or, plausibly, an alien inoculated a dead Earth during a visit several billion years ago. Some astrobiologists believe the Earth's biosphere began from living cells encapsulated within a meteorite, and another possibility is that life arose spontaneously from a non-living chemical soup, the latter idea persisting despite spontaneous generation having been refuted by the research of Louis Pasteur, a contemporary of Charles Darwin. Life did begin somehow in the distant past, and the concept of Darwinian evolution has found ample support in the biological sciences, a process influenced by each organism's phenotypic plasticity and physiological fitness to survive change. Within this evolutionary logic, we should be able to step back through geological time and identify possible sources of vascular plants followed by their attainment of increasing xylotomical complexity.

Stromatolites comprising several kinds of bacteria occur in rocks aged 3.5 billion years (Papineau et al. 2005). The primary producers in stromatolites were photosynthesizing cyanobacteria, physiologically quite complex organisms and evidence that life appeared on Earth much earlier. In the Neoproterozoic (580-542 Ma) there existed diverse kinds of multi-cellular organisms having plant-like forms (Fig. 1), but 
paleontologists consider all as benthic animals. Naumova (1949), Jacob et al. (1953), Kryschtofovitch (1953) and Ghosh and Bose (1955) reported evidence for spiny stems, wood fragments, and spores of bryophytes and pteridophytes in rocks of Cambrian age (542-488 Ma), but scientific scepticism delegated those fossils into the realm of artefacts. The present view is that liverwort-like fossils of Middle Ordovician (475 Ma) were the first land plants (Wellman et al. 2003).

A plant here designated as Archaeastirpis antiquus was discovered in what may be a Late Ordovician or an Early Silurian stratum (Fig. 2). The morphogenesis achieved by Archaeastirpis was advanced, its size and structure somewhat similar to a Monotropa species with an added taproot. It remains to be determined if Archaeastirpis had a vascular system (R.A. Savidge, unpublished data).

By Late Silurian (416 Ma), substantial morphological diversity existed among land or semi-aquatic plants (Kotyk et al. 2002), but most evidently lacked vascular tissue. Many paleobotany textbooks describe Cooksonia, a tiny fossil plant having a small central strand of primary xylem elements, as the first vascular plant on earth. However, Baragwanathia longifolia (Fig. 3) co-existed with or even preceded Cooksonia in Late Silurian, and Baragwanathia was larger and more complex, having branched stems with lycopod-like leaves. Baragwanathia likely lived within estuarine habitat, but it was also capable of conducting water through a small-diameter central cylinder of long tubular tracheids, each having spaced annular rings of secondary wall thickening (Lang and Cookson 1935). Baragwanathia evidently was incapable of secondary growth, but Late Silurian stems here designated as Caithlinia douglasii achieved at least $5 \mathrm{~cm}$ in diameter (Fig. 4). In cross section, Caithlinia stems display an outer circumferential ring appearing as cambium (R.A. Savidge, unpublished data).

Stem anatomy in some extant species informs us that cells derived from cambium need not differentiate into woody elements (Savidge 1996, 2000, 2001), and perhaps early plants like Caithlinia became competent for secondary growth before cambial derivatives had the genes and/or metabolic machinery to become woody. The earliest trees had rays as well as woody elements, and those living ray cells in wood may be a carryover from that early kind of secondary growth.

Earth's early plants had to attain a number of developmental competencies in order for trees to arise. They had to:

1) remain living for an extended duration leading into perenniality;

2) produce a lateral meristem (cambium);

3) modulate lateral vis-à-vis extension growth;

4) divide cambial cells through an extraordinary periclinal cell-division process;

5) switch off cell-division activity and turn on cell-expansion activity;

6) modify primary cell walls such that particular positions could subsequently be opened for water conduction;

7) deposit polysaccharides as discrete secondary-wall layers inside primary walls;

8) sequentially lignify the cell-wall layers;

9) undergo complete protoplasmic digestion including opening of bordered-pit channels.

At the sub-cellular level, every one of the preceding is an immensely complex phenomenon that continues to defy understanding.
The key achievement imparting woodiness and therefore the rigidity needed to defy gravity was lignification. Lignification is on the one hand the best understood aspect of woodformation biochemistry, but on the other it involves the concerted activity of many different enzymes and cell compartments and, consequently, still remains quite incompletely understood (Savidge et al. 1998, Croteau et al. 2000). Formation of lignin begins with glucose and, ignoring the events associated with transfer of carbohydrate from leaves to cambial cells, its deposition in cell walls requires concerted and ongoing catalysis by numerous enzymes in several biochemical pathways: glycolysis, oxidative pentose phosphate, shikimic acid, phenylpropanoid and at least two additional pathways regulating trans-membrane supply of lignin building blocks and their dehydrogenative polymerization.

The ability to enter into the phenylpropanoid pathway has often been regarded as the key that opened the door to lignifications. That pathway begins by deamination of the protein amino acid L-phenylalanine followed by metabolism of the resulting trans-cinnamic acid into phenylpropanoids, leading to production of phenylpropenols. It is not a lignificationcommitted pathway, however, because in conifers phenylpropenols accumulate rapidly as glucosides in non-lignifying cambial cells, only subsequently to be hydrolyzed in support of both lignification and other kinds of phenylpropanoid metabolism (Savidge and Förster 1998, Savidge et al. 1998).

It is conceivable that a genetic alteration enabled a single plant to lignify long ago, hence establishing it as the ancestor of all woody plants on earth. However, lignin is hydrophobic, and fibres do not permit passage of water unless their lignified walls have openings. Water is essential for all aspects of metabolism, photosynthesis and evaporative cooling of lightexposed leaves. It seems likely, therefore, that attainment of genetic competence for lignification was of itself insufficient change for plants to achieve tree heights.

Early Devonian (415 Ma) plants were of small stature and probably restricted to water's edge. Before plants could propagate into soils having lower water potential, a mechanism had to be found for creating openings in lignified secondary walls, enabling water to pass from one lignified element to the next and be lifted from roots to foliar organs. Those openings, known as bordered pits, have been figured and described countless times in extant and fossil woods. Bordered pits are amazing sub-cellular expressions, but their formation remains a mystery. My observations indicate that bordered pits arise through the medium of an organelle, but this organelle has only begun to be characterized (Savidge 2001, 2003). The earliest evidence for bordered-pit formation is in Early Devonian (Edwards 2003).

By Middle Devonian (394 Ma) an astonishing increase in plant size had been achieved in spore-producing progymnosperms of Archaeopteris (Scheckler 1999). Secondary xylem of Archaeopteris is known as Callixylon (Beck 1960), and it was distinct from later-produced woods in having large numbers of bordered pits grouped into discrete clusters within each tracheid (Fig. 5). These progymnosperms were the first perennial trees, some living for several decades and reaching $30 \mathrm{~m}$ in height with trunks a metre in diameter. Smaller woody, spore-producing shrubs and the first seed plants, small bushes or vines known as lyginopterids, also began to appear in Middle to Late Devonian. By the end of the Devonian, about $364 \mathrm{Ma}$, a major extinction event occurred, 


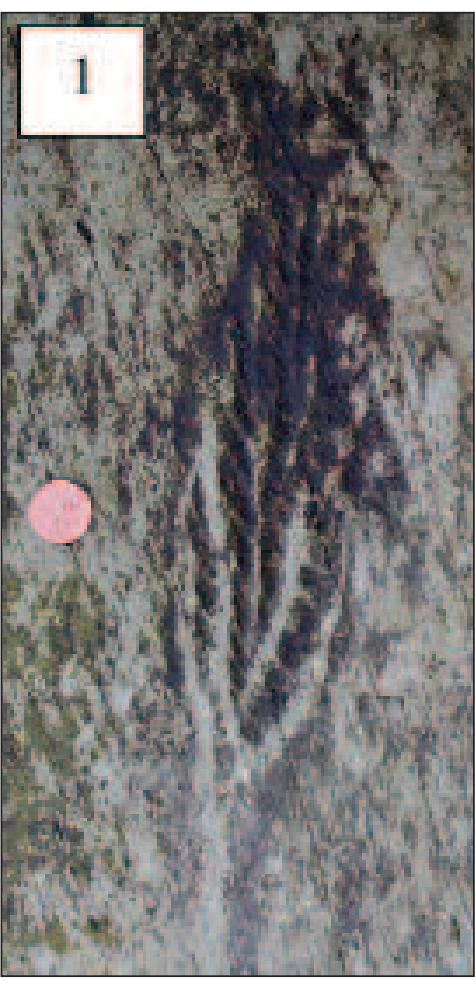

Fig. 1. Neoproterozoic (Ediacaran) fossil (Newfoundland, Canada) with plant-like form but generally assumed to be a benthic animal; the coin at left is $19 \mathrm{~mm}$ in diameter.

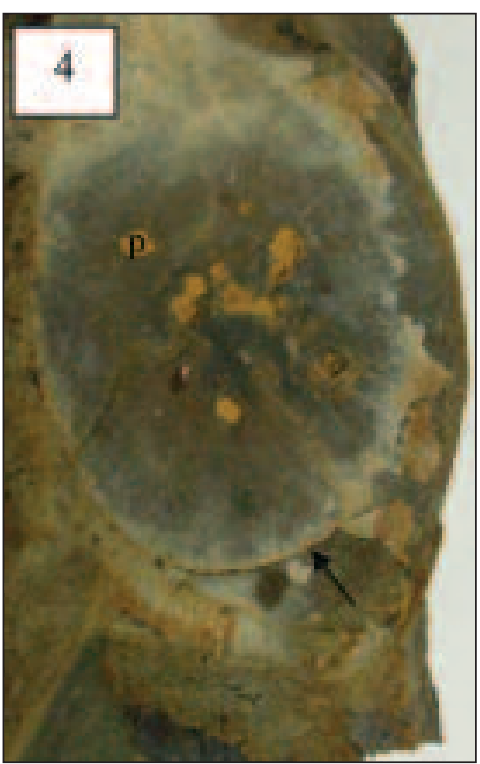

Fig. 4. Large-diameter non-woody stem with cambium (arrow) of Late Silurian (Victoria, Australia) Caithlinia douglasii. Several pyrite crystals (p) are within the tissue. Scale at right $=$ $\mathrm{mm}$.

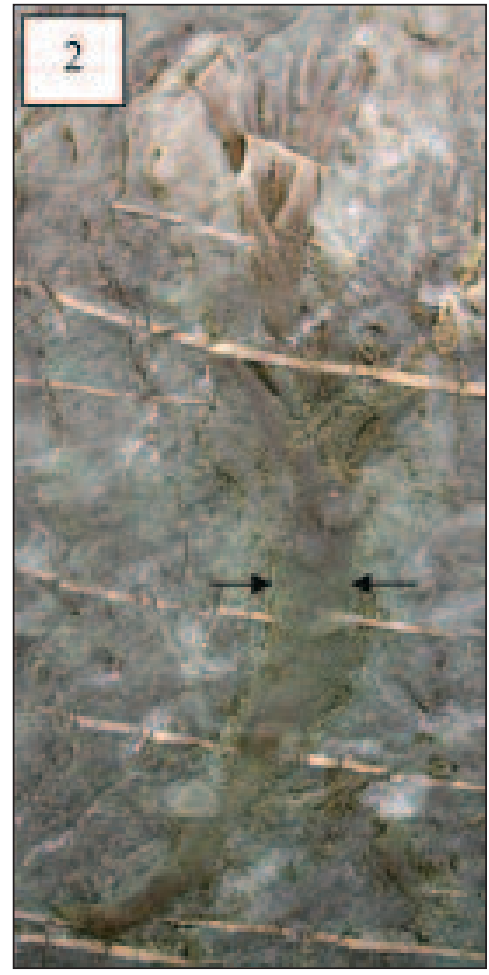

Fig. 2. Late Ordovician or Early Silurian (New Brunswick, Canada) Archaeastirpis antiquus. Stem diameter between the two arrows is $1.4 \mathrm{~cm}$.

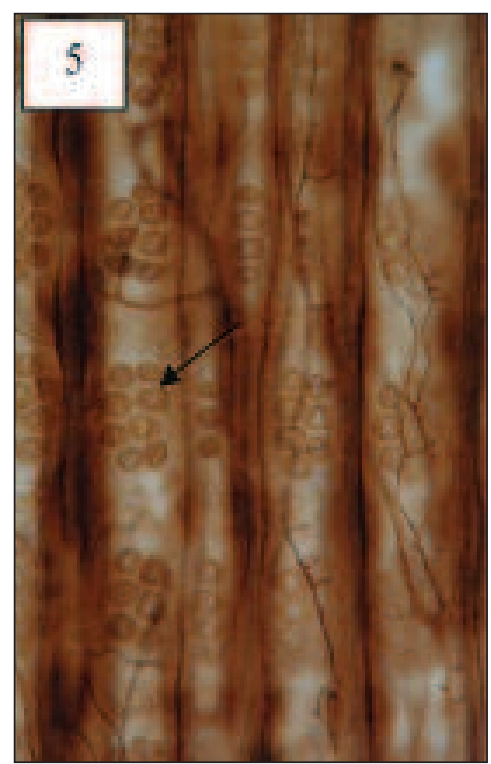

Fig. 5. Radial section of Callixylon newberryi wood with fungal hyphae. Note the grouped bordered pits lone group arrowed].

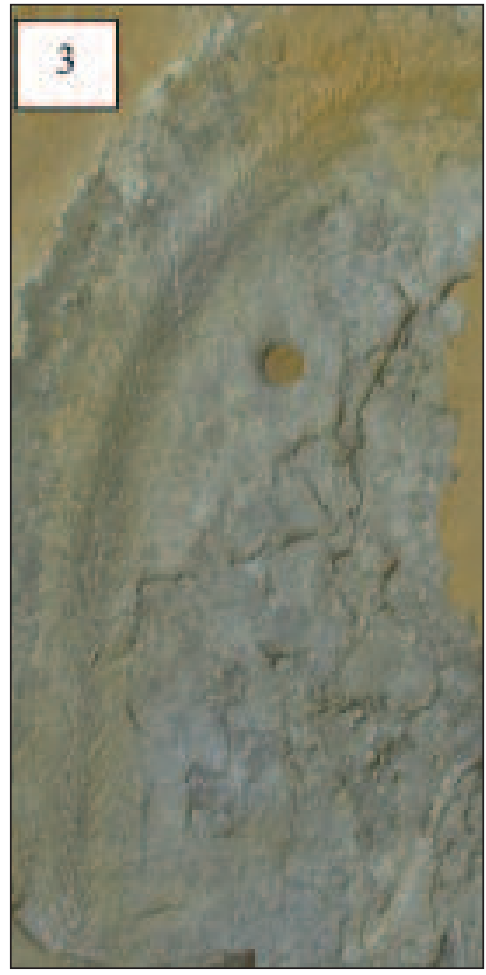

Fig. 3. Late Silurian (Victoria, Australia) Baragwanathia longifolia; the coin is $20.5 \mathrm{~mm}$ in diameter.

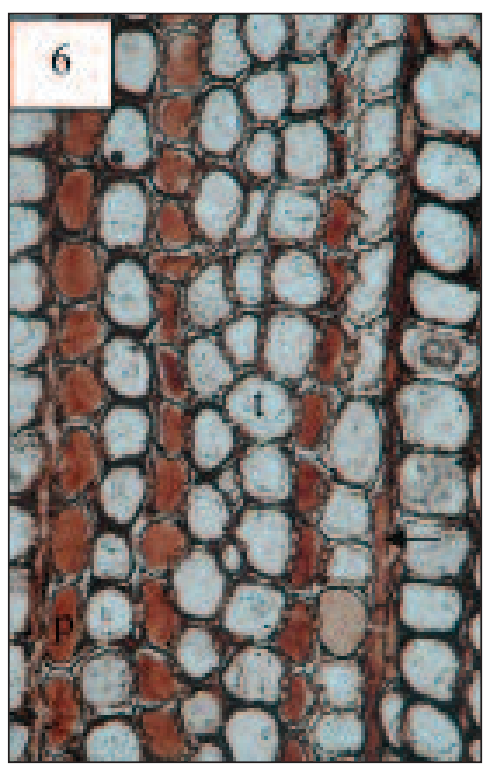

Fig. 6. Cross section of Late Mississippian Parenchoxylon hattii (New Brunswick, Canada) showing radial files of multi-pitted tracheids ( $t$ ), axial parenchyma (p) and rays (arrow). 
but Archaeopteris survived and seed plants continued diversifying and marching toward the dominance they would achieve in the ensuing Carboniferous.

In addition to the tree-sized horsetail Calamites and lycopsids such as Lepidodendron, several important groups of seed plants arose during the Carboniferous period, including seed ferns, cordaites, glossopterids, conifers, and cycads. There are many morphotypes of these in the fossil record, and almost all are extinct. The earliest known conifers are from that Carboniferous stage referred to as Desmoinian (308-306.5 Ma) in North America and as Middle Westphalian (315-306.5 $\mathrm{Ma}$ ) in Europe (Hernandez-Castillo et al. 2001, Looy 2007). A recent find of conifer-like stems here designated as Parenchoxylon hattii (Fig. 6) is estimated at $323 \mathrm{Ma}$ (R.A. Savidge, unpublished data). When the Carboniferous ended (299 Ma), conifers were locally common but still a relatively minor component of the flora on earth. Ginkgos appeared in Late Carboniferous or soon thereafter, and conifer and ginkgo species increased during the Permian (299-251 Ma), with conifers becoming the dominant flora in many locales by the end of the Permian. The Permian ended with the greatest mass extinction event in earth's history, destroying an estimated $95 \%$ of all species, but some trees survived. By Late Triassic (228-200 Ma) when dinosaurs were first appearing on earth, conifers with woods quite similar to what are found in modern Cupressaceae and Araucariaceae were beginning to emerge (Savidge 2007). Many millions of years were still to pass, and new developmental competencies attained, before Pinaceae and hardwoods made their appearances.

\section{Epilogue}

The fossil record reveals that the physiological competence needed to achieve and integrate the nano-processes underlying wood formation was not acquired overnight, rather over many millions of years, but this protracted evolution led to one of the most awe-inspiring and enduring kinds of life on Earth, possibly the one most important for the continuing existence of the biosphere. My career has been devoted to understanding those nano-processes, but the only thing I yet know with certainty is that an immense research effort is still needed. The "easy" investigations into wood formation were done long ago. The difficult questions have also been investigated, some like cellulose biosynthesis and lignification innumerable times, but like fossil wood the secrets of wood formation in living trees remain hidden.

The better we understand the physiology of a species, the better we will be able to anticipate what should be done to ensure that it continues to exist. Within both evolutionary and modern-day forestry perspectives, the fundamental nano-developments underlying diameter growth in trees are cambium formation and maintenance; bordered-pit, cellulose and lignin formation in cambial derivatives; protoplasmic autolysis of the resulting woody elements; and secondary metabolism in non-autolyzed sapwood cells. The biochemistries of primary metabolism, dormancy and perenniality are essential aspects operating in the background. All are also indirectly essential for height growth. None is well understood.

There presently are more paleobotanists working on fossil woods than there are biophysicists, biochemists, cell and molecular biologists combined working on vascular cam- bium. The fact that there are very few cambium researchers in the world is a curious phenomenon in forest science, particularly when considered in relation to the much more robust scientific activities in fields of wood science, tree "improvement," ecological forestry, dendrochronology, and management of forest productivity, all of which have their basis in wood formation. The limited research effort into the fundamentals of wood formation is also a major void within the overall effort of plant science. In recent decades, massive support has been provided for fundamental research into growth, development and functioning of Arabidopsis thaliana, a small annual flowering plant, serving as a "model" organism for flowering plants in general. Magnoliophyta including Arabidopsis appeared on Earth relatively recently, and the value of the Arabidopsis program in relation to advancing understanding of the physiology of gymnosperms and more primitive plants is uncertain. The many bright young scientists active in Arabidopsis research know little about wood, ecosystems, or forestry, but their activity now dominates plant science. In relation to the global abundance and environmental importance of the seven Pinophyta families, also cycads, gnetae, gingko, seed ferns and cryptogams, there is ample justification for having comparable programs involving representative organisms. No song and dance about economic rewards should be needed. The pursuit of scientific knowledge into the primary producers, on which all of terrestrial life depends, simply for knowledge's sake, is ample justification. The research will undoubtedly aid humanity in maintaining Earth not only as habitable but as a beautiful place.

\section{Acknowledgements}

The fossil in Fig. 3 was disclosed to me by Dr. Jack Douglas (deceased 2007). Fig. 5 was produced from a specimen provided by University of Michigan Museum of Paleontology. UNB technician Calvin Nash prepared thin sections for Figs. 5 and 6.

\section{References}

American Museum of Natural History. 1998. National survey reveals biodiversity crisis - scientific experts believe we are in midst of fastest mass extinction in earth's history. Press Release no. 20, April 20.

Ash, S.R. and R.A. Savidge. 2004. The bark of the Late Triassic Araucarioxylon arizonicum tree from Petrified Forest National Park, Arizona. IAWA J. 25: 349-368.

Beck, C.B., 1960. Connection between Archaeopteris and Callixylon. Science 131: 1524-1525.

Croteau, R., T.M. Kutchan and N.G. Lewis. 2000. Natural products (secondary metabolites), In B. Buchanan, W. Gruissem and R. Jones (eds.). Biochemistry and molecular biology of plants. pp. 1250-1318. American Society of Plant Physiologists, Rockville, MD.

Edwards, D. 2003. Xylem in early tracheophytes. Plant, Cell and Environ. 26: 57-72.

Evelyn, J. 1664. Sylva, or, a discourse of forest-trees, and the propagation of timber in his majesties dominions. Pt. 1, pp. 1-120. J. Martyn and J. Allestry, London.

Ghosh, A.K. and A. Bose. 1955. Did vascular plants exist in Cambrian times? Nat. Inst. Sci. India Bull. 7:298-303.

Hernandez-Castillo, G.R., G.W. Rothwell and G. Mapes. 2001. Thucydiaceae Fam. Nov., with a review and reevaluation of Paleozoic Walchian conifers. Int. J Plant Sci. 162: 1155-1185.

Jacob, K., C. Jacob and R.N. Shrivasta. 1953. Evidence for the existence of vascular land plants in the Cambrian. Current Sci. 22: 34-36. 
Kotyk, M., J.F. Basinger, P.G. Gensel and T.A. DeFreitas. 2002. Morphologically complex plant macrofossils from the Late Silurian of Arctic Canada. Am. J. Bot. 89: 1004-1013.

Kryschtofovitch, A. 1953. Discovery of Lycopodium (Lycopodiaceae) in the Cambrian deposits of eastern Siberia (in Russian). Doklady Acad. Sci. USSR 91: 1377-1379.

Labandeira, C.C. 2006. The four phases of plant-arthropod associations in deep time. Geologica Acta 4: 409-438.

Lang, W.H. and I.C. Cookson. 1935. On a flora, including vascular land plants, associated with Monograptus, in rocks of Silurian age, from Victoria, Australia. Phil. Trans. Royal Soc. B 224: 421-449.

Looy, C.V. 2007. Extending the range of derived Late Paleozoic conifers: Lebowskia gen. nov. (Majonicaceae). Int. J. Plant Sci. 168: 957-972.

May, R.M. 1988. How many species are there on earth? Science 247: 1441-1449.

Mayhew, P.J., G.B. Jenkins and T.G. Benton. 2008. A long-term association between global temperature and biodiversity, origination and extinction in the fossil record. Proc. Royal Soc. B: 275: 47-53.

Naumova, C.N. 1949. Spores of the Lower Cambrian (in Russian). Acad. Sci. USSR Bull. Geol. Ser. 4: 49-56.

Papineau, D., J.J. Walker, S.J. Mojzsis and N.R. Pace. 2005. Composition and structure of microbial communities from stromatolites of Hamelin Pool in Shark Bay, Western Australia. Appl. Env. Microbiol. 71: 4822-4832.

Savidge, R.A. 1996. Xylogenesis, genetic and environmental regulation - a review. IAWA J. 17: 269-310.

Savidge, R.A. 2000. Biochemistry of seasonal cambial growth and wood formation - an overview of the challenges. In R.A. Savidge, J. Barnett and R. Napier (eds.). Cell and molecular biology of wood formation. pp. 1-30. BIOS Scientific, Oxford.

Savidge, R.A. 2001. Intrinsic regulation of cambial growth. J. Plant Growth Reg. 20: 52-77.

Savidge, R.A. 2003. Tree growth and wood quality. In J.R. Barnett and $\mathrm{G}$. Jeronimidis (eds.). Wood quality and its biological basis. pp. 1-29. Blackwell and CRC Press, Oxford and Boca Raton, Florida.
Savidge, R.A. 2006. Xylotomic evidence for two new conifers and a ginkgo within the Late Triassic Chinle Formation of Petrified Forest National Park, Arizona, USA. In W.G. Parker, S.R. Ash and R.B. Irmis (eds.). A century of research at Petrified Forest National Park: geology and paleontology. Museum of Northern Arizona Bulletin no. 62:147-149.

Savidge, R.A. 2007. Wood anatomy of Late Triassic trees in Petrified Forest National Park, Arizona, USA, in relation to Araucarioxylon arizonicum Knowlton, 1889. Bull. Geosci. 82: 301-328.

Savidge, R.A. and S.R. Ash. 2006. Arboramosa semicircumtrachea, an unusual Late Triassic tree in Petrified Forest National Park, Arizona, USA. In W.G. Parker, S.R. Ash and R.B. Irmis (eds.). A century of research at Petrified Forest National Park: geology and paleontology. Museum of Northern Arizona Bulletin no. 62: 65-81.

Savidge, R.A. and J.L. Farrar. 1984. Cellular adjustments in the vascular cambium leading to spiral grain formation in conifers. Can. J. Bot. 62: 2872-2879.

Savidge, R.A. and H. Förster. 1998. Seasonal activity of uridine 5'diphosphoglucose: coniferyl alcohol glucosyltransferase in relation to cambial growth and dormancy in conifers. Can. J. Bot. 76: 486-493.

Savidge, R.A., P.V. Udagama-Randeniya, Y. Xu, V. Leinhos, and H. Förster. 1998. Coniferyl alcohol oxidase, a new enzyme spatiotemporally associated with lignification. In N.G. Lewis and S. Sarkanen (eds.). Lignin and lignan biosynthesis, ACS Symposium Series 697: 109-130.

Scheckler, S.E. 1999. Progymnosperms. In R. Singer (ed.). Encyclopedia of Paleontology. Vol. 2(M-Z), pp. 992-995. Fitzroy Dearborn, Chicago and London.

Thomas, C.D., A. Cameron, R.E. Green, M. Bakkenes, L.J. Beaumont, Y.C. Collingham, B.F.N. Erasmus, M.F. de Siqueira, A. Grainger, L. Hannah, L, Hughes, B. Huntley, A.S. van Jaarsveld, G.F.Midgley, L. Miles and M.A. Ortega-Huerta. 2004. Extinction risk from climate change. Nature 427: 147-148.

Wellman, C.H., P.L. Osterloff and U. Mohiuddin. 2003. Fragments of the earliest land plants. Nature 422: 282-285. 